\title{
EFFECT OF SEROTONIN ON FOOD INTAKE BY PIGLETS DURING THE EARLY POSTNATAL PERIOD
}

\author{
EVA BARANYIOVÁ \\ Department of Physiology, University of Veterinary Science, 61242 Brno
}

Received March 29, 1990

\begin{abstract}
Baranyiová Eva: Effect of Serotonin on Food Intake by Piglets During the Early Postnatal Period. Acta vet. Brno, 60, 1991: 127-136.

The effect of serotonin (5-HT) on the consumption of a liquid diet was investigated in 32 Large White $\times$ Landrace piglets from 1 to $24 \mathrm{~d}$ after birth in 2 experimental series. The piglets were housed individually in cages and were offered a commercial milk diet, Selasan, for sucking from feeding bottles 9 times a day at $2-\mathrm{h}$ intervals with an 8-h break at night.

Serotonin (5-hydroxytryptamine creatinine sulphate, Sigma) was administered to piglets ( $\mathrm{n}=3$ to 6 ) in $0.01 \%$ and $0.05 \%$ solution invariably 10 minutes before feeding at $1,2,3,5,7,9,14,18,21,22$ and $24 \mathrm{~d}$ after birth in single i.p. doses of 0.05 to $1.00 \mathrm{mg} \cdot \mathrm{kg}^{-1}$. Control piglets were intact (series I) or treated with saline (series II) in volumes corresponding to those of $0.05 \mathrm{mg} \cdot \mathrm{kg}^{-1} 5-\mathrm{HT}$ doses.

Compared with the amount of diet consumed before and after 5-HT injection, the dose of $0.01 \mathrm{mg} \cdot \mathrm{kg}^{-1} 5-\mathrm{HT}$ reduced the food intake at 9 and $18 \mathrm{~d}$ by $48 \%$ and at $21 \mathrm{~d}$ by $82 \%$. The dose of $0.05 \mathrm{mg} \cdot \mathrm{kg}^{-1} 5-\mathrm{HT}$ reduced the food intake at $3 \mathrm{~d}$ by $58 \%$, at $5 \mathrm{~d}$ by $50 \%$, at $7 \mathrm{~d}$ by $93 \%$, at 9 d by $82 \%$, at $18 \mathrm{~d}$ by $85 \%$, at $21 \mathrm{~d}$ by $94 \%$ and at $22 \mathrm{~d}$ by $55 \%$. The dose of $0.1 \mathrm{mg} \cdot \mathrm{kg}^{-1}$ reduced the food intake of piglets at $1 \mathrm{~d}$ by $86 \%$, at $3 \mathrm{~d}$ by $94 \%$ and at $21 \mathrm{~d}$ after birth by $99 \%$. All above-mentioned reductions in food intake were significant. The higher doses inhibited food consumption completely in piglets aged 2,5 and $7 \mathrm{~d}$.

The results of the experiment using 16 times repeated 5-HT injection provided unequivocal evidence that 5-HT exerts a suppressive effect on diet consumption by piglets from 1 to $24 \mathrm{~d}$ after birth and that the extent of this suppression is dose-dependent. Moreover, changes were also recorded in the quality of consumption, i.e. in feeding behaviour, and after injection of the higher doses, hyperaemia of the skin and a stimulatory effect on intestinal peristalsis were observed.

It is concluded that the serotoninergic system as part of aminostatic food intake regulation is functional already in newborn piglets.
\end{abstract}

Early-weaned piglets, feeding behaviour, food intake, regulation

Postnatal development of the functions of the serotoninergic system has received relatively little attention (Wils on et al. 1986; O hi et al. 1988; Manjarréz et al. 1988; Hamon et al. 1989). On the basis of their experiments on newborn rats Ristine and Spear (1984) suggested that serotonin and acetylcholine are indispensable for the stimulation of some components of the sucking ritual of rat pups during the early postnatal period.

Administered to adult animals by the central or peripheral routes, serotonin (5-HT) reduces their food intake and also affects food selection and the pattern of feeding behaviour: it reduces the rate of food consumption, which is also finished earlier, and brings about changes in intra-meal and inter-meal intervals (Soulairac and Soulairac 1960; Blundell 1977; Pollock and Rowland 1981; Wurtman and Wurtman 1984; Blundell 1986; Kanarek and Dushkin 1988; Neill and Cooper 1989). Serotoninergic manipulations therefore exert a number of influences; 
in adult animals (most data have been reported for rats) it may primarily accelerate the termination of feeding rather than block its initiation. These findings have been interpreted as enhancement of satiation (Blundell 1986, 1988; Le ibowit z and Shor-Posner $1986 \mathrm{ab}$ ).

Very few data are available on the action of the 5-HT system in the young of farm animals. In piglets, peripheral administration of 5-HT precursor, tryptophan, exerts a suppressive effect on food intake from as early as the 3rd postnatal day (Baranyiova $1990 \mathrm{ab}$ ). The object of the present study was to find whether and in which way peripherally administered serotonin influences food consumption in piglets during the early postnatal period.

\section{Materials and Methods}

The experimental animals were 32 Large White $\times$ Landrace piglets weaned on the 1st day after birth from their clinically healthy mothers kept under conventional conditions of a large-scale production unit. The piglets were then transported to the laboratory where they were weighed and housed individually in cages as described previously (Holub 1964; Baranyiová et al. 1985; Baranyiová and Holub 1989).

The piglets were injected i.p. with serotonin (5-hydroxytryptamine creatinine sulphate complex, Sigma, USA) freshly diluted with saline to the concentration of $0.05 \%$ (experimental series I) and $0.01 \%$ (experimental series II). In a preliminary experiment on 2 piglets aged $12 \mathrm{~d}$ the dose of $1 \mathrm{mg} \cdot \mathrm{kg}^{-1}$ (Pollock and Rowland 1981) produced, besides the anorexigenic effect, instantaneous peripheral vasodilatation and somnolence. The anorexigenic effect of 5-HT appeared 2 to 4 minutes after 5-HT administration and continued for about 30 to 40 minutes. One-way analysis of variance showed that the intervals of 2, 4 and 10 minutes between 5-HT administration and the commencement of feeding had no influence on meal size. The piglets were therefore offered the diet for sucking 10 minutes after 5-HT administration.

In experimental series I the following single doses of 5-HT were used: $1 \mathrm{mg} \cdot \mathrm{kg}^{-1}$ (at $2 \mathrm{~d}$ ), $0.5 \mathrm{mg}$. . $\mathrm{kg}^{-1}$ and $0,05 \mathrm{mg} \cdot \mathrm{kg}^{-1}$ (at $5 \mathrm{~d}$ ), $0.25 \mathrm{mg} \cdot \mathrm{kg}^{-1}$ (at $7 \mathrm{~d}$ ) and $0.1 \mathrm{mg} \cdot \mathrm{kg}^{-1}$ (at 1, 3 and $21 \mathrm{~d}$ after birth). Control piglets were left untreated.

In experimental series II the single 5-HT doses were as follows: $0.05 \mathrm{mg} \cdot \mathrm{kg}^{-1}$ was administered to piglets at $3,7,9,14,18,21,22$ and $24 \mathrm{~d}$, and $0.01 \mathrm{mg} . \mathrm{kg}^{-1}$ to piglets at $7,9,14,18,21,22$ and $24 \mathrm{~d}$ after birth. Control piglets were injected with saline in doses corresponding in volume to $0.05 \mathrm{mg} \cdot \mathrm{kg}^{-1}$ 5-HT at 7, 9, 14, 18, 21 and $24 \mathrm{~d}$ and were intact at $22 \mathrm{~d}$ after birth. The experimental and control groups were alternated.

In experimental serries I where the higher doses $(0.25,0.5$ and $1.0 \mathrm{mg})$ of $5-\mathrm{HT}$ were used a marked stimulatory effect on peristalsis was observed (the intestinal contents passed between about 15 and 20 minutes after 5-HT administration were dark and pasty and those passed up to 40 to 50 minutes after administration were dark and liquid). The doses of 0.05 and $0.01 \mathrm{mg} \cdot \mathrm{kg}^{-1}$ used in experimental series II had the anorexigenic effect without influence on the gastrointestinal tract as observed in experimental series I.

Consumption of the diet was expressed in relation to body mass. The results of the experiment were assessed by one-way analysis of variance; Student's t-test was used in those cases where the depression of consumption was less than $100 \%$.

\section{Results and Discussion}

Intraperitoneal administration of 5-HT had a suppressive effect on the food intake of the piglets throughout the experimental period. The consumption of the diet by experimental piglets was reduced, compared both with their food intakes at the feedings preceding and following the injection and also with the food intake by intact or saline-treated controls (Fig. 1, 2, 3 and 4; Table 1).

The higher 5-HT doses administered in experimental series I blocked food intake completely in piglets aged 2,5 and $7 \mathrm{~d}$ receiving $1 \mathrm{mg} . \mathrm{kg}^{-1}, 0.5 \mathrm{mg} \cdot \mathrm{kg}^{-1}$ and $0.25 \mathrm{mg} . \mathrm{kg}^{-1}$, respectively (Fig. 1 and 2). The reduction of the dose to $0.1 \mathrm{mg}$. . $\mathrm{kg}^{-1}$ produced a significant decrease in food intake on the 1st day, i.e. as soon as $14 \mathrm{~h}$ after birth, and then at 3 and $21 \mathrm{~d}$, with diet consumption declining to $14 \%, 6 \%$ and $0.8 \%$ of the means of the preceding and following intakes. 
d 1

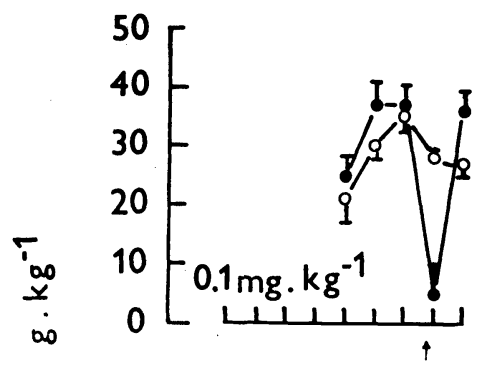

d 3

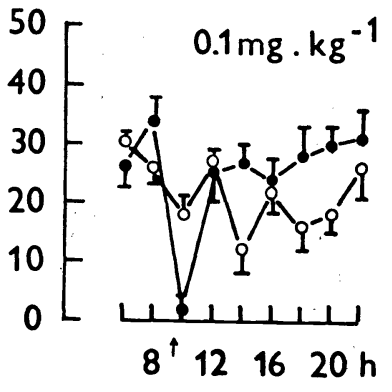

- control intact
5-HT

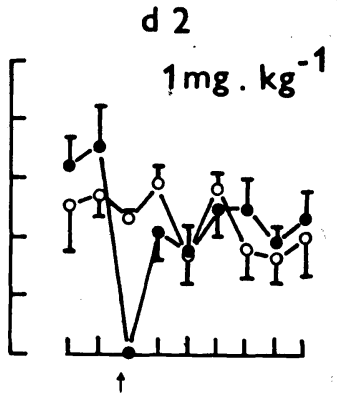

d 5

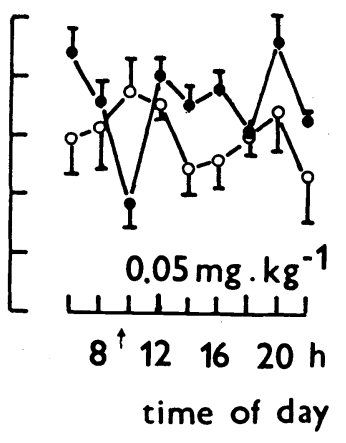

Fig. 1. Rela tive diet consumption by serotonin-injected piglets at idividual meals. Series $I$. Piglets 1 to $5 \mathrm{~d}$ after birth. The arrows indicated the 5-HT injections.

In experimental series II where the 5 -HT doses were even lower $(0.05$ and $0.01 \mathrm{mg} \cdot \mathrm{kg}^{-1}$ ) and the controls were sham-injected with saline, the food intake of the experimental animals declined significantly to about $50 \%$, compared with intact controls from series I except at 14 and $24 \mathrm{~d}$ (Fig. 3 and 4; Table 1) and with saline-injected controls except at 14, 18, 21 and $24 \mathrm{~d}$. A marked decrease in diet consumption was also found in comparison with the food intakes on the days preceding and following 5-HT injection; this decrease was significant except at 14 and $24 \mathrm{~d}$. The decrease in diet consumption in response to the lowest dose, $0.01 \mathrm{mg} . \mathrm{kg}^{-1}$, was significant at 9, 18 and $21 \mathrm{~d}$ (Table 1 ).

Assessment of the results by one-way analysis of variance demonstrated a significant effect of the size of 5-HT dose on diet consumption by piglets at $3 \mathrm{~d}[\mathrm{~F}(2,10)=$ $=19.51 ; \mathrm{P}<0.01], 5 \mathrm{~d}[\mathrm{~F}(2,12)=22.5 ; \mathrm{P}<0.01), 7 \mathrm{~d}[\mathrm{~F}(4,15)=12.86$; $\mathrm{P}<0.01], 9 \mathrm{~d}[\mathrm{~F}(3,22)=8.95 ; \mathrm{P}<0.01), 21 \mathrm{~d}[\mathrm{~F}(4,15)=284 ; \mathrm{P}<0.01]$ and at $22 \mathrm{~d}[\mathrm{~F}(2,8)=24.1 ; \mathrm{P}<0.01]$, but not at 14,18 and $24 \mathrm{~d}$.

Changes were found not only in the quantity but also in the quality of food consumption. In the youngest piglets the 2nd sucking phase was prolonged and the 3rd phase showed a slow-down of the sucking movements. In the older ani- 
mals, up to $24 \mathrm{~d}$, the $2 \mathrm{nd}$ phase appeared once again, delaying the beginning of sucking; this was not only slowed down but also shortened. The only manifestation of feeding behaviour in piglets receiving the higher 5-HT doses $(0.25$ to 1.00 $\mathrm{mg} . \mathrm{kg}^{-1}$ ) was search for the nipple and massage imitation against the cage wall with their eyes half-closed; these animals did not even mouth the nipple of the feeding bottle and only performed massage movements near the bottle and fell asleep. They looked as if they were only in process of learning the sucking procedure.

This finding is of particular interest in light of the observations made in adult animals. Thus according to Blundell (1986) peripheral administration of 5-HT accelerates the termination of food intake rather than blocks its initiation. Leibowitz and Shor-Posner (1986a), in their study on rats injected with 5-HT into the nucleus paraventricularis, reported that the size of meals and the rate of feed consumption were significantly reduced but that no changes occurred in either the period elapsing before the initiation of food intake or the frequency of the meals. All this suggests that although 5-HT administration exerts a suppressive effect on food intake in both young and adult animals, different components of their feeding behaviour are affected.

Published data on the young of mammals along this line are scarce. Ristine and Spear (1984) tested the serotoninergic system of rats during their postnatal

d 5
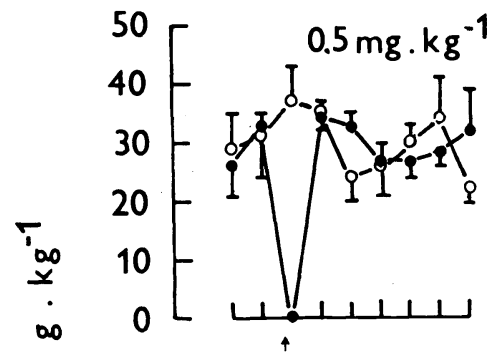

d 9

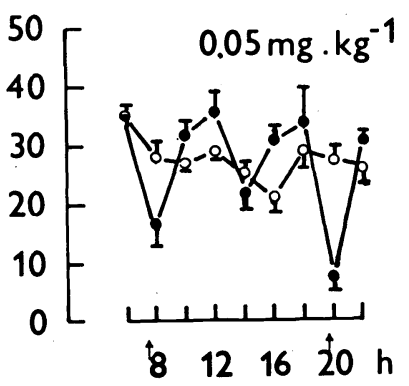

d 7

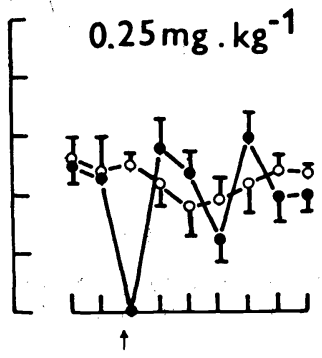

d 21

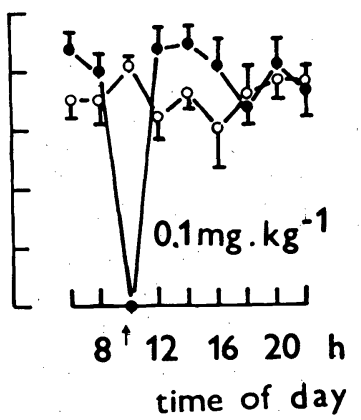

Fig. 2. Relative diet consumption by serotonin-injected piglets at indivudal meals. Series I. Piglets 5 to $21 \mathrm{~d}$ after birth. 
d 3

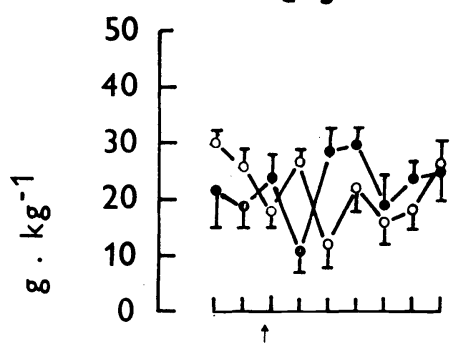

d 9

¿ำ

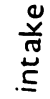
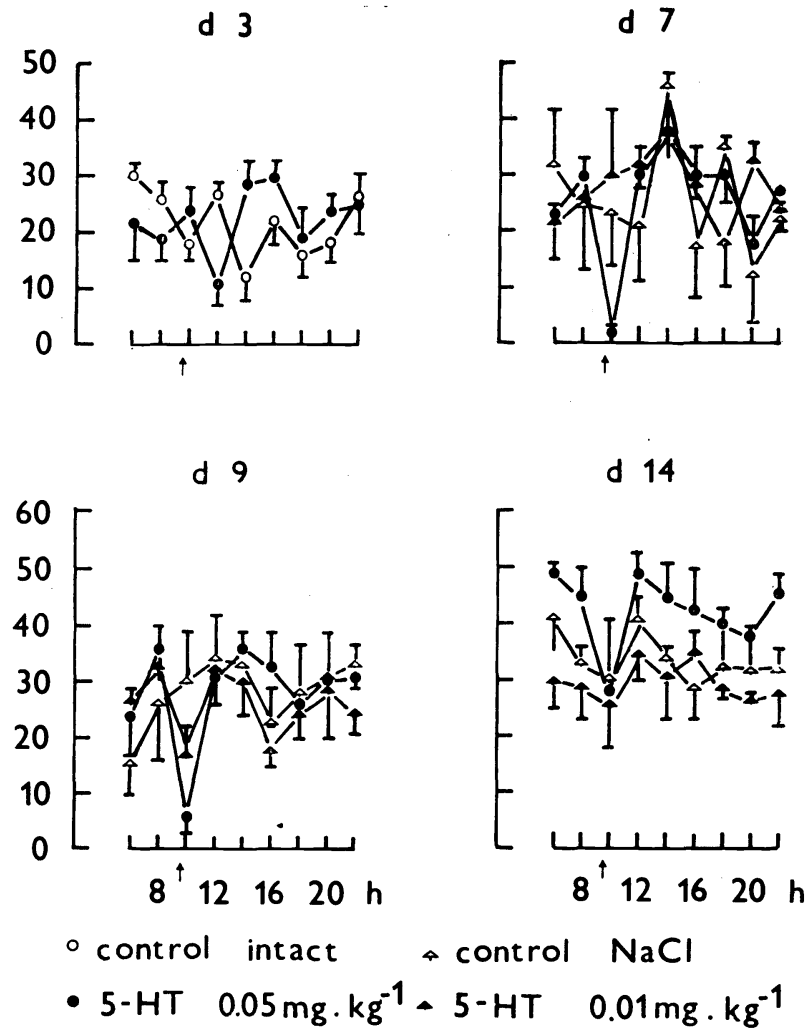

Fig. 3. Relative diet consumption by serotonin-injected piglets at individual meals. Series II. Piglets 3 to $14 \mathrm{~d}$ after birth.

period by subcutaneous administration of its antagonist (metergoline) and measured the sucking time. This was shortened markedly at 3 to $4 \mathrm{~d}$ after birth, depending on the dose; this effect then gradually declined, disappearing at $24 \mathrm{~d}$. Affected were also other components of the feeding behaviour (body movements, paddling with forelimbs, treading with hindlimbs, etc.). The authors concluded that the 5-HT system is indispensable to the initiation of sucking and that 5-HT and acetylcholine are crucial factors for some components, of feeding behaviour during the early postnatal period. Serotoninergic modulation of the behaviour of newborn babies (soothing effect and sleep) by administration of dietary tryptophan was suggested by Yogman and Zeisel (1985). Soothing effect and sleep were also observed in our experimental piglets within 2 to 3 minutes of 5-HT administration.

In addition of the afore-mentioned 5-HT effects its higher doses $(0.5$ and 1.00 $\mathrm{mg} \mathrm{.} \mathrm{kg}^{-1}$ ) produced short-term hyperaemia of the skin and, in some piglets, signs of discomfort: restlessness, vomitus (2 animals) and severe diarrhoea appearing repeatedly, often also in sleep, for almost $1 \mathrm{~h}$ after 5-HT administration.

Acceleration of the motility of the small intestine of fasted conscious dogs was also observed after i.v. infusion of 5-HT (150 to $1200 \mu \mathrm{g} \cdot \mathrm{kg}^{-1} \cdot \mathrm{h}^{-1}$ ) by Pilot et al. (1983).

Piglets given 5-HT at $0.1 \mathrm{mg} \cdot \mathrm{kg}^{-1}$ and in lower doses showed no signs of dis- 
d 18

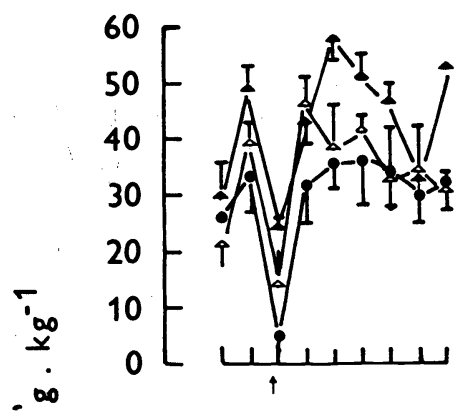

d 22

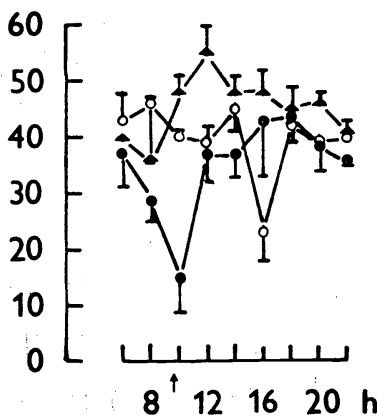

d 21

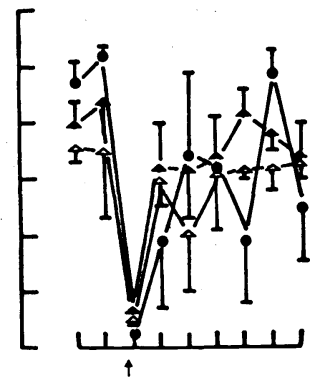

d 24

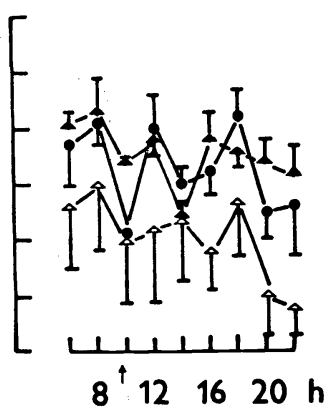

Fig. 4. Relative diet consumption by serotonin-injected piglets at individual meals. Series II. Piglets 18 to $24 \mathrm{~d}$ after birth.

comfort and defecated formed faeces generally within 20 to 30 minutes of 5-HT administration. No stimulation of intestinal peristalsis at all was observed in piglets given $5-\mathrm{HT}$ at the rate of $0.01 \mathrm{mg} \cdot \mathrm{kg}^{-1}$.

From comparison of the data reported by other investigators (Soulairac and Soulairac 1960, Pollock and Rowland 1981, Kanarek and Dushkin 1989) with our findings, considerable inter-species differences in the sensitivity to 5-HT become apparent. In adult rats $5-\mathrm{HT}$ administered at $3 \mathrm{mg} \cdot \mathrm{kg}^{-1}$ (Soulairac and Soulairac 1960), 0.5 to $5 \mathrm{mg} . \mathrm{kg}^{-1}$ (Pollock and Rowland 1981) or at 2 to $6 \mathrm{mg} \mathrm{.} \mathrm{kg}^{-1}$ (Kanarek and Dushkin 1989) produced no signs of discomfort of the animals and no stimulatory effect on their intestinal peristalsis was described. According to Pollock and Rowland (1981) the $\mathrm{ED}_{50}$ of serotonin for food consumption by rats is $2 \mathrm{mg} . \mathrm{kg}^{-1}$.

In piglets, on the other hand, 5-HT doses of $0.1,0.25$ and $1 \mathrm{mg} . \mathrm{kg}^{-1}$ administered during the 1st postnatal month stopped food consumption completely, the dose of $0.05 \mathrm{mg} \mathrm{.} \mathrm{kg-1}$ ( 40 times lower than the $\mathrm{ED}_{50}$ in rats) decreased it by $40 \%$ to $94 \%$ depending on age and even the dose of $0.01 \mathrm{mg} \cdot \mathrm{kg}^{-1}$ (200 times lower than the $\mathrm{ED}_{50}$ in rats) decreased the food intake by $19 \%$ to $82 \%$ in 5 instances out of 7 administrations.

5-HT administered to mammals peripherally does not pass through the haema- 
Table 1

Design of the experiments and summary of statistical assessment

\begin{tabular}{|c|c|c|c|c|c|}
\hline \multirow{2}{*}{ Age } & \multicolumn{3}{|c|}{$5-\mathrm{HT} \mathrm{mg} \cdot \mathrm{kg}^{-1}$} & \multicolumn{2}{|c|}{ Controls } \\
\hline & 0.01 & 0.05 & 0.1 & Intact & Saline-treated \\
\hline 1 & & & $(n=5) c$ & $(n=10) c$ & \\
\hline 3 & & $(n=4)$ NS & $(n=5) c$ & $(\mathrm{n}=10) \mathrm{b}(0.1 \mathrm{mg})$ & \\
\hline 5 & & $(\mathrm{n}=5)_{\mathrm{a}}^{\mathrm{a}}$ & & $(\mathrm{n}=5) \mathrm{a}^{\mathrm{b}(0.05 \mathrm{mg})}$ & \\
\hline 7 & $(n=3)$ NS & $(n=4)^{a}$ & & $(\mathrm{n}=5) \quad \mathrm{c}(0.01 \mathrm{mg})$ & $(n=3)$ NS \\
\hline 9 & $(n=4)$ b & $(n=9) c$ & & $\begin{array}{r}\mathrm{b}(0.05 \mathrm{mg}) \\
(\mathrm{n}=10) \mathrm{b}(0.01 \mathrm{mg})\end{array}$ & $(\mathrm{n}=3) \stackrel{\mathrm{b}}{\mathrm{NS}}(0.05 \mathrm{mg})$ \\
\hline 14 & $(n=4)$ NS & $(\mathrm{n}=3) \stackrel{\mathrm{c}}{\mathrm{NS}}$ & & c $(0.05 \mathrm{mg})$ & $(\mathrm{n}=3) \stackrel{\mathrm{a}}{\mathrm{NS}}(0.05 \mathrm{mg})$ \\
\hline 18 & $(n=4) b$ & $(n=3)$ a & & $(\mathrm{n}=10) \mathrm{c}(0.01 \mathrm{mg})$ & $(n=3)$ NS \\
\hline & 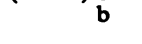 & b & & $\begin{array}{l}c(0.05 \mathrm{mg}) \\
c(0.01 \mathrm{mg})\end{array}$ & NS \\
\hline 21 & $(n=4) c$ & $(n=3) c$ & $(n=5) c$ & $(\mathrm{n}=5) \quad \mathrm{c}(0.05 \mathrm{mg})$ & $(\mathrm{n}=3)$ NS \\
\hline 22 & $(\mathrm{n}=4) \underset{\text { NS }}{\mathrm{NS}}$ & $(\mathrm{n}=3)$ NS & & $(\mathrm{n}=3) \quad \stackrel{\mathrm{c}}{\mathrm{NS}(0.1 \mathrm{mg})} \mathrm{mg})$ & c \\
\hline 24 & $(n=4) \underset{\text { NS }}{\text { NS }}$ & $(\mathrm{n}=3) \underset{\text { NS }}{\text { NS }}$ & & & $(\mathrm{n}=3) \underset{\text { NS }}{\mathrm{NS}}$ \\
\hline
\end{tabular}

Numbers of treated piglets $(\mathrm{n}), \mathrm{a}=\mathrm{P}<0.05, \mathrm{~b}=\mathrm{P}<0.01, \mathrm{c}=\mathrm{P}<0.001, \mathrm{NS}=$ Difference not significant

Signifiicant differences in food intake of piglets indicated by letters $\mathrm{a}, \mathrm{b}$ and $\mathrm{c}$ as against the feedings preceding (upper line) and following (lower line) the ones affected by serotonin aministration, and against intact and saline-treated controls. No diet was consumed by piglets treated with $0.25,0.5$ and $1.0 \mathrm{mg} \cdot \mathrm{kg}^{-1}$ serotonin.

toencephalic barrier (Oldendorf 1971) and its anorexigenic effect is mediated by peripheral receptors (Neill and Cooper 1989). It can be assumed that its effect in piglets is also peripheral.

In contrast to the experiments conducted on other species, mammals (Neill and Cooper 1989) or birds (Bara nyiová 1988, 1990), where the effects of 5-HT were generally studied under conditions of free access to feed, the food intake of piglets in the present study was limited to 9 meals a day during which the piglets could consume the diet to satiety. This experimental design enabled us to assess the short-term effect of serotonin on diet consumption in comparison, e.g., with the action of an amino acid mixture (Baranyiová et al. 1985, 1987; Baranyiová and Holub 1989), and 5-HT precursor, tryptophan (Baranyiová 1990ab).

The results of our experiments ( 16 trials) demonstrated that 5-HT exerts a depressive effect on food consumption of piglets from 1 to $24 \mathrm{~d}$ after birth, i.e. during the suckling period as well as during the weaning period, and that 5-HT effects are dose dependent. In addition to the suppressive effect on food intake, changes were also observed in the behaviour of the piglets, particularly in their feeding behaviour. Therefore the serotoninergic system which can be regarded as part of aminostatic component of food intake regulation is functional already in newborn piglets.

\section{Vliv serotoninu na konzum potravy selat $\mathrm{v}$ raném postnatálním údobí}

Vliv serotoninu na konzum tekuté diety byl sledován na 32 selatech (křižencích plemene bílé ušlechtilé $\times$ landrace) od 1 . do 24 . dne po narozeni ve dvou pokusných sériích. Selata byla odchovávána individuálně v klecích a $\mathrm{k}$ sání jim byla na- 
bízena dieta Selasan $9 \times$ denně ve dvouhodinových intervalech $\mathrm{s}$ 8hodinovou noční přestávkou.

Serotonin (5-HT, 5-hydroxytryptamine creatinine sulphate, Sigma, USA) v 0,01 a $0,05 \%$ roztoku byl selatủm $(n=3$ až 6$)$ jednorázově i.p. aplikován vždy 10 min před krmením, a to v 1., 2., 3., 5., 7., 9., 14., 18., 21., 22. a 24. dne v dávkách od 0,01 do $1,0 \mathrm{mg} \mathrm{.} \mathrm{kg}^{-1}$. Selata kontrolní byla intaktní (1. série) anebo ošetřena fyziologickým roztokem (2. série).

Ve srovnání s množstvím diety zkonzumované před a po aplikaci 5-HT v dávce $0,01 \mathrm{mg} \cdot \mathrm{kg}^{-1}$ konzum diety selat byl snížen 9 . a 18. dne o $40 \%$ a 21 . dne o $82 \%$. Dávkou $0,05 \mathrm{mg} \cdot \mathrm{kg}^{-1}$ byl konzum snižen 3. dne o $58 \%$, 5. dne o $50 \%$, 7. dne o $93 \%$, 9. dne o $82 \%$, 18. dne o $85 \%$, 21. dne o $94 \%$, 22. dne o $55 \%$. Dávkou $0,1 \mathrm{mg} \cdot \mathrm{kg}^{-1}$ byl konzum snížen 1 . dne o $86 \%$, 3. dne o $94 \%$ a 21 . dne o $99 \%$. Všechny uvedené změny byly statisticky významné. Vyšší dávky u selat 2,5 a 7 denních konzum diety zcela inhibovaly.

Výsledky pokusu s 16krát opakovanou aplikací jednoznačně prokázaly, že 5-HT působí na konzum diety depresivně od 1 . do 24 . dne a že hloubka této deprese je závislá na dávce 5-HT. Vedle depresivního účinku na velikost konzumu byly zaznamenány i změny $\mathrm{v}$ jeho kvalitě, tij. změny $\mathrm{v}$ nutričním chování selat, při vyšších dávkách 5-HT i prokrevní kůže a stimulační vliv na enterální motoriku. Lze tedy vyvozovat, že serotoninergni systém, jako součást aminostatického řízení přijmu potravy, je funkční již u novorozených selat.

\section{Влияние серотонина на потребление пищи поросят в ранний постнатальный период}

Проводили исследования влияния серотонина на потребление жидкой диеты у 32 поросят (помесь белой породистой породы и ландрас) с 1 по 24 сутки после рождения в двух опытных сериях. Поросят выращивали в клетках, подавали диетическую пищу Селасан 9 раз в день с двухчасовыми нитервалами и восьмичасовым ночным перерывом.

Серотонин (5-окситриптамин креатинин сульфат, Сигма, США, 5-HT) дозой 0,01 и $0,05 \%$ раствора поросятам ( $\mathrm{n}=3-6$ ) однократно интраперитонеально вводили всегда за 10 минут до кормления, а именно на 1, 2, 3, 5, 7, 9, 14, 18, 21, 22, 24 сүтки дозами от 0,05 до 1,00 мг.кг-1. Контрольные поросята были интактные (1 серия) или получали физиологический раствор (2 серия).

По сравнению с количеством диеты, потребляемой перед и после дачи 5-HT 0,01 мг.кr-1 5-HT потребление диеты поросятами уменьшипось на 9 и 18 сутки на $48 \%$ и 21 сүтки на $82 \%$. Дозой 0,05 мг.кг-1 5-НТ потребление сократилось на 3 сутки на $58 \%$, на $50 \%, 7$ сутки на $93 \%, 9$ сутки на $82 \%, 18$ сүтки на $85 \%, 21$ сүтки на $94 \%, 22$ сутки на $55 \%$. Дозой 0,1 мг.кг-1 5-НТ потребление диеты сократилось на 1 сутки на $86 \%, 3$ сутки на $94 \%$ и 21 сүтки на $99 \%$. Более высокие дозы у поросят в возрасте 2,5 и 7 суток потребление диеты полностью притормозили.

Результаты эксперимента с 16 раз повторяемым применением явно выявили, что 5-НТ оказывает депрессивное воздействие на потребление диеты с 1 по 24 сутки и глубина депрессии потребления диеты зависит от подаваемой дозы. Наряду с депрессивным воздействием на 
интенсивность потребления отмечались также изменения качества потребления, т. е. изменения в поведении поросят при кормлении, при более высоких дозах также изменения в кровоснабжении кожи и стимулирующее влияние на энтеральную моторику. Следовательно, серотонергическая система в качестве составной части аминостатического регулирования приема пищи действует уже у новорожденных поросят.

\section{References}

BARANYIOVÁ, E.-STANDARA, S.-HOLUB, A.: Ontogenesis of food intake regulation in the young of farm animals. (In Czech). Project report, University of Veterinary Science, Brno, 1985: $32 \mathrm{p}$.

BARANYIOVA, E. - STANDARA, S. - HOLUB, A. : Vliv aminokyselin na príjem potravy u selat v prvém měsíci života. Čs. fysiol., 36, 1987: 179

BARANYIOVÁ, E.: Effect of intraperitoneal administration of serotonin on food intake of chickens aged 1 to 25 days. Physiol. bohemoslov. 37, 1988: 552

BARANYIOVÁ, E.: Vliv serotoninu na konzum potravy selat $\mathrm{v}$ raném postnatálním údobí. Čs. fysiol., 36, 1989: 337

BARANYIOVÁ, E.: Effect of intraperitoneal administration of tryptophan on food intake of piglets on a liquid diet. Comptes rendus, Réunion commune, Praha 1990a: p. 12

BARANYIOVÁ, E.: Food intake regulation in the young of farm animals. (In Czech). Project report, University of Veterinary Science, Brno, 1990b: $83 \mathrm{p}$.

BARANYIOVÁ, E.: Effect of serotonin on the food intake in chickens in the early post-hatching period. Acta vet. Brno, 59, 1990c: 23-33

BARANYIOVA, E.- HOLUB, A.: Effect of intraperitoneal administration of amino acids on the food intake of piglets on a liquid diet during the first month after birth. Physiol. bohemoslov., 38, 1989: 267-274

BLUNDELL, J. E.: Is there a role of serotonin (5-hydroxytryptamine) in feeding ? Int. J. Obesity, 1, 1977: $15-42$

BLUNDELL, J. E.: Serotonin manipulations and the structure of feeding behaviour. Appetite, 7, 1986: $39-56$

BLUNDELL, J. E. : Role of monoamine systems in the control of food intake and nutrient selection. In: Modulation of Neural Function Academic Press, New York, 1988: pp. 95-123

HAMON, M. - BOURGOIN, S. - CHANEZ, C. - De VITRY, F.: Do serotonin and other brain neurotransmitters exert a trophic influence on the immature brain? Develop. Neurobiology, ed. Evrard P. - Minkowski A., Nestlé Nutrition Workshop Series, Vol. 12, Nestec Ltd.,Vevey/ Raven Press, New York, 1989: pp. 171-183

HOLUB, A.: Weight gains of piglets reared on a semisynthetic high-caloric diet in the first month of life. (In Czech). Živoč. výr., 8 (36), 1964: 539-544

KANAREK, R. B.-DUSHKIN, H.: Peripheral serotonin administration selectively reduces fat intake in rats. Pharmacol. Biochem. Behav., 31, 1988: 113-122

LEIBOWITZ, S. F.-SHOR-POSNER, G.: Hypothalamic monoamine systems for control of food intake: analysis of meal patterns and macronutrient selection. Pharmacology of Eating Disorders: Theoretical and Clinical Developments, 1986a: 29-49

LEIBOWITZ, S. F. - SHOR-POSNER, G.: Brain serotonin and eating behavior. Appetite, 7, 1986b: $1-14$

MANJARRÉZ, G.-CHABOYA, G.-HERNÁNDEZ, J.: Perinatal serotonin metabolism in rats malnourished in utero. Biol. Neonate, 54, 1988: 232-240

NEILL, J. C. - COOPER, S. J.: Effect of 5-hydroxytryptamine and d-fenfluramine on sham feeding and sham drinking in gastric-fistulated rats. Physiol. Behav., 46, 1989: 949-953

OHI, K.-HAYASHI, S. - TAKAHASNI, K.: Development of circadian rhythms in rats with lesions of serotonergic system. Physiol. Behav., 44, 1988: 393-403

OLDENDORF, W. H.: Brain uptake of radiolabeled amino acids, amines, hexoses after arterial injection. Am. J. Physiol., 22, 1971: 1629-1639

PILOT, M. A.-THOMPSON, H. H.-ZARA, G. P.: Effect of 5-hydroxytryptamine on canine intestinal motility during fasting. J. Physiol., 343, 1983: p. 88-89

POLLOCK, J. D. - ROWLAND, N.: Peripherally administered serotonin decreases food intake in rats. Pharmac. Biochem. Behav., 15(2), 1981: 179-183

RISTINE, L. A. - SPEAR, L. P.: Effects of serotonergic and cholinergic antagonists on suckling behavior of neonatal, infant, and weaning rat pups. Behav. Neural Biol., 41, 1984: 99-126 
SOULAIRAC, A. - SOULAIRAC, M. L.: Action de la réserpine, de la sérotonine et de l'iproniazide sur le comportement alimentaire du Rat. C. R. Soc. Biol., 154, 1960: 510-513

WILSON, C. A.-PEARSON, J. R.-HUNTER, A. J.-TUOHY, P. A.-PAYNE, A.P.: The effect of neonatal manipulation of hypothalamic serotonin levels on sexual activity in the adult rat. Pharmacol. Biochem. Behav., 24, 1986: 1175-1183

WURTMAN, R. J. - WURTMAN, J. J.: Nutrients, neurotransmitters synthesis, and the control of food intake. In: Eating and its Disorders, ed. Stunkard, A. J. - Stellar, E., Raven Press, New York, 1984, pp. 77-86

YOGMAN, M. W.-ZEISEL, S. H.: Nutrients, neurotransmitters and infant behavior. Am. J. Clin. Nutr., 42, 1985: 352-360 